\title{
Variation of wood density and mechanical properties of blackwood (Acacia melanoxylon R. Br.)
}

\author{
José Saporiti Machado a , José Luís Louzada ${ }^{\mathrm{b}}$, António J.A. Santos ${ }^{\mathrm{c}, \mathrm{d}, \mathrm{e}}$, Lina Nunes ${ }^{\mathrm{a}}$, Ofélia Anjos ${ }^{\mathrm{c}, \mathrm{f}, *}$, \\ José Rodrigues ${ }^{e}$, Rogério M.S. Simões ${ }^{d}$, Helena Pereira ${ }^{c}$ \\ ${ }^{a}$ Laboratório Nacional de Engenharia Civil, Departamento de Estruturas de Madeira, Avenida do Brasil, 101, 700-066 Lisboa, Portugal \\ ${ }^{\mathrm{b}}$ Centro de Investigação e de Tecnologias Agro-Ambientais e Biológicas (CITAB), Departamento Florestal, Universidade Trás-os-Montes e Alto Douro (UTAD), \\ 5001-801 Vila Real, Portugal \\ ${ }^{\mathrm{c}}$ Centro de Estudos Florestais, Instituto Superior de Agronomia, Universidade Lisboa, Tapada da Ajuda, 1349-017 Lisboa, Portugal \\ ${ }^{\mathrm{d}}$ Research Unit of Textile and Paper Materials, Universidade da Beira Interior, 6201-001 Covilhã, Portugal \\ e Tropical Research Institute of Portugal (IICT), Forestry and Forest Products Centre, Tapada da Ajuda, 1349-017 Lisboa, Portugal \\ ${ }^{\mathrm{f}}$ Instituto Politécnico de Castelo Branco, Escola Superior Agrária, Apartado 119, Castelo Branco, Portugal
}

\section{A R T I C L E I N F O}

\section{Article history:}

Received 12 August 2013

Accepted 7 December 2013

Available online 15 December 2013

\section{Keywords:}

Acacia melanoxylon

Wood density

Mechanical properties

\begin{abstract}
A B S T R A C T
The variation of wood density and mechanical properties with site, tree and within tree (longitudinal and radial) were studied for blackwood (Acacia melanoxylon $\mathrm{R}$. Br.) grown in four sites in Portugal. Twenty trees were randomly selected ( $40 \mathrm{~cm}$ dbh class, 33-51 years of age), sampled at three stem height levels ( $5 \%, 35 \%$ and $65 \%$ of tree height) and three radial positions ( $10 \%, 50 \%$ and $90 \%$ of radius). They were further tested for air-dry density at $12 \%$ moisture content, bending strength (MOR), modulus of elasticity (MOE) and compression strength parallel to grain (CS), using ISO standards.

The overall mean properties of blackwood were: $654 \mathrm{~kg} \mathrm{~m}^{-3}$ density, $139 \mathrm{~N} \mathrm{~mm}^{-2}$ MOR, $141 \times 10^{2}$ $\mathrm{N} \mathrm{mm}^{-2} \mathrm{MOE}$ and $61 \mathrm{~N} \mathrm{~mm}^{-2} \mathrm{CS}$. Site was not a significant source of variation for all wood properties. The variation between individual trees was the most important. Within the tree, the radial variation was highly significant for all traits, while the longitudinal variation was only significant for density. The correlation of density with the mechanical properties was moderate.

Blackwood showed potential for being an alternative species to supply the industry with valuable hardwood timber. The significant differences found between the trees demonstrate the possibility of selection and improvement for increased wood quality.
\end{abstract}

(c) 2013 Elsevier Ltd. All rights reserved.

\section{Introduction}

Blackwood (Acacia melanoxylon R. Br.) is a highly valued timber species for carpentry and cabinet making. It has great decorative wood qualities and is classed within an elite group which includes walnut, mahogany and teak [1,2]. Blackwood grows in eastern Australia over a wide latitudinal range from north Queensland $\left(16^{\circ} \mathrm{S}\right)$ to Southern Tasmania $\left(43^{\circ} \mathrm{S}\right)$, and westwards into South Australia [3]. Blackwood was introduced into Europe as an ornamental timber and is now established as a forest plantation species in many countries including South Africa, New Zealand, Vietnam, China and Chile [3].

Blackwood was introduced in mainland Portugal, at the beginning of the twentieth century in state owned dry and poor sandy

\footnotetext{
* Corresponding author at: Instituto Politécnico de Castelo Branco, Escola Superior Agrária, Apartado 119, Castelo Branco, Portugal. Tel.: +351 272229900; fax: +351 272339901 .

E-mail address: ofelia@ipcb.pt (O. Anjos).
}

soils along the coast, mainly for dune protection; the present estimated area for Acacia spp. is 5331 hectares in pure and mixed stands, mainly with maritime pine, and mostly uneven-aged and uneven-sized [4]. These state-owned stands are subject to selective cuttings for sawlog-sized timber dimension ( $40 \mathrm{~cm}$ diameter) and the Blackwood logs have considerable market value for the production of solid wood products. However, little is known about the wood properties of European Blackwood [5,6], except for recent reports on its heartwood variation [7] and pulp production potential [8-12].

One of the most important properties of lignocellulosic materials is density due to its effect on strength, performance and the general quality of final products [13-17].

Blackwood is a medium to high density hardwood with a large variation range: in New Zealand in 70-year-old trees basic density ranges from 465 to $670 \mathrm{~kg} \mathrm{~m}^{-3}$ [2], and in Argentina for 9-12 and 26-32 year old trees it ranges from 414 to $589 \mathrm{~kg} \mathrm{~m}^{-3}$ [18]. A large variation was also reported in the basic density of sapwood 
(494-740 $\mathrm{kg} \mathrm{m}^{-3}$ ) and heartwood (583-987 $\mathrm{kg} \mathrm{m}^{-3}$ ) for Chilean Blackwood trees [19].

Within the stem, the basic wood density was reported to vary very little with height in New Zealand blackwood trees [2], while a significant decrease with height was found in Argentinian trees [18]. The basic density varied considerably over the radial profile, increasing with cambial age [2,20], although Aguilera and Zamora [19] reported higher density for heartwood than for sapwood.

Blackwood is highly appreciated due to medium bending properties, high crushing strength and resistance to impact, which are all important properties for structural uses $[2,6]$. However, the published information is insufficient for a detailed quantification of blackwood mechanical properties and for the potential variation to be found between trees or sites. Results published previously [21] have already suggested the value of blackwood grown in Portugal, and those results are completed by the present study.

The overall objective of this study is to contribute to enhancing the use of blackwood in Europe as a high value timber species by a detailed characterization of its wood quality in what relates to density and mechanical properties. The aim is to show that European grown blackwood may compete with other woods i.e. tropical woods, in quality wood components. As such we investigated the variability of wood density and mechanical properties of European grown blackwood in relation to, within and between tree variation as well as the respective site influence. A. melanoxylon trees grown in four sites located in northern and central Portugal and with different edaphoclimatic conditions were investigated by harvesting 20 mature trees at the end of rotation.

\section{Material and methods}

\subsection{Sampling}

Twenty blackwood (A. melanoxylon $\mathrm{R}$. Br.) trees were sampled from four state-owned mixed stands with maritime pine (Pinus pinaster Aiton.) in Portugal. The location and details of the four sites and of the sampled trees are given in Table 1, as already previously described [21]. The trees were harvested at the end of rotation for sawlog-size timber dimension $(40 \mathrm{~cm}$ over bark diameter at breast height) corresponding to an age between 35 and 49 years. Five trees were randomly selected in each site. Diameter at $1.3 \mathrm{~m}$ height (d.b.h.) was determined as the mean of two crossdiameters. After felling, total height and the height from base to $7 \mathrm{~cm}$ diameter were measured.

A $40 \mathrm{~cm}$ long disk was taken at different height levels (at 5\%, $35 \%$ and $65 \%$ of total tree height) [7]. The $5 \%$ height level was close to the breast height level.
Table 2

Variance components for ANOVA.

\begin{tabular}{ll}
\hline Source & Variance components \\
\hline Site $(S)$ & $\sigma^{2} r+\operatorname{rdl} \sigma^{2} T / S+\operatorname{rdlt} \sigma^{2} S$ \\
Tree/site $(T / S)$ & $\sigma^{2} r+\operatorname{rdl} \sigma^{2} T / S$ \\
Height level $(L)$ & $\sigma^{2} r+\operatorname{rdts} \sigma^{2} L$ \\
$L \times S$ & $\sigma^{2} r+\operatorname{rd} \sigma^{2} L T S+\operatorname{rdt} \sigma^{2} L S$ \\
$L \times T / S$ & $\sigma^{2} r+\operatorname{rd} \sigma^{2} L T S$ \\
Radial position $(P)$ & $\sigma^{2} r+\operatorname{rlts} \sigma^{2} P$ \\
$P \times S$ & $\sigma^{2} r+\operatorname{rl} \sigma^{2} P T / S+\operatorname{rlt} \sigma^{2} P S$ \\
$P \times T / S$ & $\sigma^{2} r+\operatorname{rl} \sigma^{2} P T / S$ \\
$P \times L$ & $\sigma^{2} r+\operatorname{rts} \sigma^{2} P L$ \\
$P \times L \times S$ & $\sigma^{2} r+\operatorname{r} \sigma^{2} P L T / S+\operatorname{rt} \sigma^{2} P L S$ \\
$P \times L \times T / S$ & $\sigma^{2} r+\operatorname{rr} \sigma^{2} P L T / S$ \\
$R / P / L / T / S$ & $\sigma^{2} \mathrm{r}$ \\
\hline
\end{tabular}

$l=4 ; a=5 ; n=3 ; p=3 ; r=1.63$.

From each disk, specimens $(20 \times 20 \times 340 \mathrm{~mm}$, radial $\times$ tangential $\times$ axial) were cut at three distances from the pith $(10 \%$, $50 \%$ and $90 \%$ of the radius length) on both sides (North and South). The specimens were conditioned to constant mass at a temperature of $20 \pm 2{ }^{\circ} \mathrm{C}$ and a relative humidity of $65 \% \pm 5 \%$ and maintained in this condition until required for testing. The average moisture content of the test pieces after this stage was $12 \%$. Specimens for wood density and compression tests were sampled from the ends of the bending specimens after failure, if no mechanical damage was observed.

\subsection{Wood density and mechanical testing}

Wood density was assessed at $12 \%$ moisture content according to the ISO 3131 standard [22]. The bending strength (MOR) and modulus of elasticity (MOE) were determined by a three-point bending test according to ISO 3133 standard [23]. Compression parallel to the grain was performed in a $250 \mathrm{kN}$ universal testing machine, with $1 \%$ load accuracy, and the displacement was measured using the machine cross-head displacement, with a $1 \%$ deformation accuracy. Compression strength (CS) and modulus of elasticity (MOE) was determined according to ISO 3787 standard [24].

\subsection{Data analysis}

Analysis of variance (ANOVA) for all wood traits was performed according to the model shown in Table 2 to test the significance of site, tree, height level and radial position effects. Trees were considered as random effects, and the other sources of variation

Table 1

Site and blackwood trees characteristics.

\begin{tabular}{|c|c|c|c|c|}
\hline Site & Camarido National Forest & $\begin{array}{l}\text { Ovar Dunes Forest Perimeter, } \\
\text { Vala da Maceda }\end{array}$ & Rebordões/Santa Maria Forest Perimeter & Crasto Mountain Forest Perimeter \\
\hline & MNC & PFDOVM & PFRSM & PFC \\
\hline Tree age $^{a}$ (years) & $34-49$ & $37-48$ & $40-48$ & $37-52$ \\
\hline Longitude & $8^{\circ} 43^{\prime} \mathrm{W}$ & $8^{\circ} 34^{\prime} \mathrm{W}$ & $8^{\circ} 34^{\prime} \mathrm{W}$ & $7^{\circ} 56^{\prime} \mathrm{W}$ \\
\hline Altitude (m) & 8 & 7 & 154 & 548 \\
\hline Rainfall $\left(\mathrm{mm} \mathrm{yr}^{-1}\right)$ & 1427 & 1152 & 1720 & 1229 \\
\hline Mean temperature $\left({ }^{\circ} \mathrm{C}\right)$ & 14.3 & 13.9 & 14.0 & 13.0 \\
\hline Soil origin & Sand & Sand & Granite & Granite \\
\hline $\mathrm{DBH}(\mathrm{cm})$ & $39.6 \pm 1.6$ & $39.2 \pm 3.1$ & $41.1 \pm 3.5$ & $41.0 \pm 2.9$ \\
\hline Total height (m) & $30.4 \pm 3.6$ & $33.0 \pm 2.2$ & $28.7 \pm 2.5$ & $28.6 \pm 2.9$ \\
\hline Height to top (m) & $24.0 \pm 1.7$ & $29.7 \pm 2.1$ & $23.1 \pm 3.2$ & $24.1 \pm 3.1$ \\
\hline Number of rings at $\mathrm{DBH}$ & $33-47$ & $36-47$ & $39-47$ & $34-51$ \\
\hline
\end{tabular}

\footnotetext{
a Measured by ring counting at the stem base.
} 
as fixed effects. Variance components for the sources of variation were also estimated.

Correlation coefficients between density and mechanical properties were calculated at tree level $(n=20)$ considering the average values per tree, and at the specimen's level considering all the validated results by linear regression analysis using the least squares method. Statistical analysis was performed using the JMP Statistica software (SAS Institute Inc.).

\section{Results and discussion}

\subsection{Wood density}

The overall air-dry density (at $12 \%$ moisture content) of blackwood was on average $654 \mathrm{~kg} \mathrm{~m}^{-3}$, with an average range between sites from 614 to $668 \mathrm{~kg} \mathrm{~m}^{-3}$ (Table 3). Site was not a significant source of variation of wood density and it was the tree-to-tree variation within a site the most important source of variation, explaining $30 \%$ of the total variation (Table 4). Although the variation within each site was large for all cases (Fig. 1), it was in site PFDOVM that the largest range was found with tree mean values from 450 to $850 \mathrm{~kg} \mathrm{~m}^{-3}$.

The radial variation of density was highly significant and the most important within-tree source of variation, accounted for $16 \%$ of the total variation. The density increased from the $10 \%$ to the $50 \%$ radial position, followed by stabilization up to $90 \%$ of the distance (Fig. 2). The pattern of variation was independent of site (Table 4 , where $S * P$ was not significant, although the site PFDOVM showed an increasing trend from pith to bark (Fig. 2), but varied between trees i.e. the interaction was highly significant and accounted for $10 \%$ of the total variation. The variance explained by this interaction may result from the internal variability of the trees as well as from other factors that were not studied here, namely the climate conditions during growth. The different behavior observed for site PFDOVM could be explained by a lower stand density associated to more favorable soil and lower rainfall.

The longitudinal variation was highly significant but contributed little to the total variation (Table 4). The density increased

Table 3

Average values per site for wood density and mechanical properties of blackwood.

\begin{tabular}{lcccc}
\hline Site & MNC & PFDOVM & PFRSM & PFC \\
\hline Density $-12 \%\left(\mathrm{~kg} \mathrm{~m}^{-3}\right)$ & $667 \pm 66$ & $614 \pm 86$ & $668 \pm 53$ & $665 \pm 80$ \\
MOR $\left(\mathrm{N} \mathrm{mm}^{-2}\right)$ & $143 \pm 31$ & $126 \pm 28$ & $146 \pm 28$ & $141 \pm 32$ \\
MOE $\times 10^{2}\left(E_{0}\right)\left(\mathrm{N} \mathrm{mm}^{-2}\right)$ & $146 \pm 22$ & $132 \pm 25$ & $145 \pm 20$ & $142 \pm 22$ \\
CS $\left(\mathrm{N} \mathrm{mm} m^{-2}\right)$ & $63 \pm 8$ & $58 \pm 8$ & $63 \pm 6$ & $60 \pm 7$ \\
\hline
\end{tabular}

MOR - bending strength; MOE - modulus of elasticity; CS - compression strength

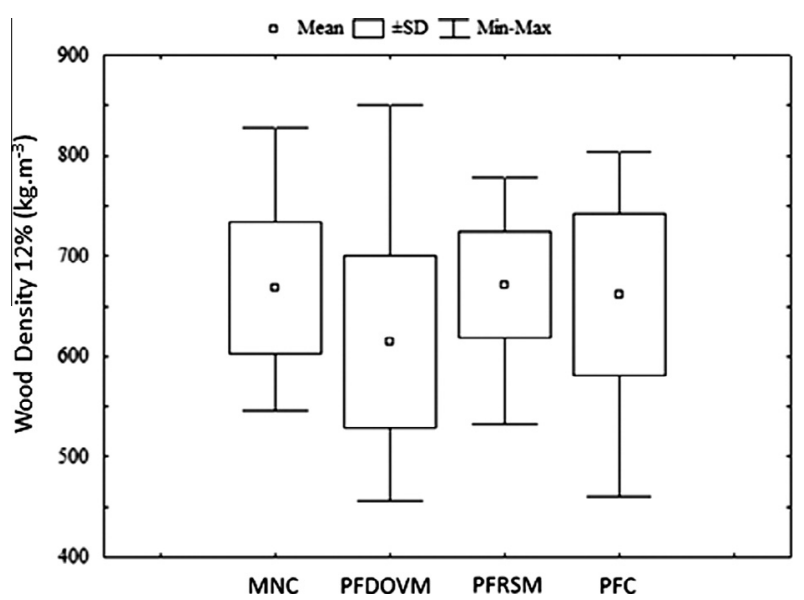

Fig. 1. Wood density variation (at $12 \%$ moisture content) for blackwood trees grown in four different sites. (SD - Standard deviation; Min-Max - minimum observed value - maximum observed value).

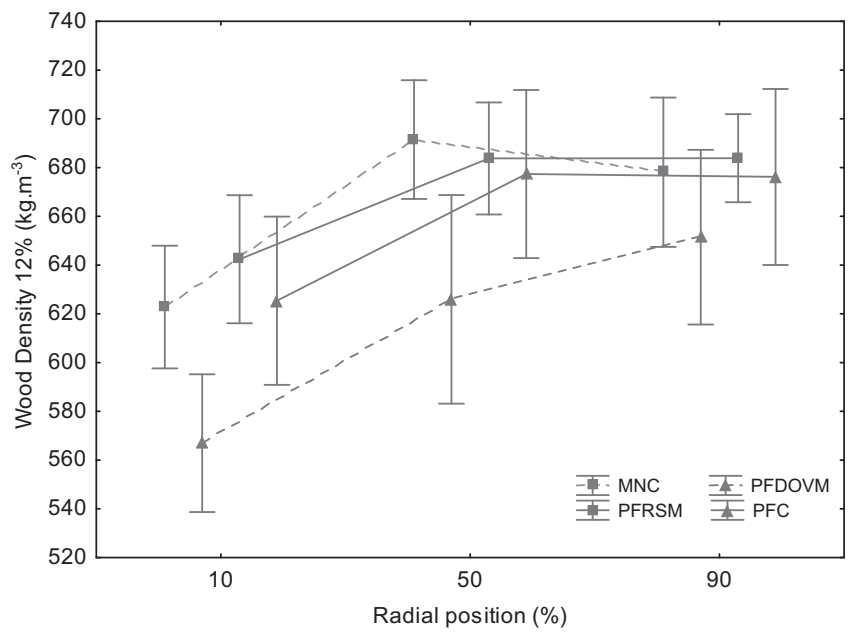

Fig. 2. Radial variation of wood density at $12 \%$ moisture content by site, for blackwood trees (mean and standard deviation).

with the height level more notably from the 35\% to the $65 \%$ tree height. This pattern was the same for all sites (Fig. 3), but could vary between trees i.e. the interaction was highly significant (Table 4).

Table 4

Variance components for density at $12 \%$ moisture content and mechanical properties of blackwood.

\begin{tabular}{|c|c|c|c|c|c|c|c|c|c|}
\hline & \multirow[t]{2}{*}{ df } & \multicolumn{2}{|c|}{ Density - 12\% } & \multicolumn{2}{|l|}{$\mathrm{MOR} f \mathrm{~m}$} & \multicolumn{2}{|l|}{ MOE $E_{0}$} & \multicolumn{2}{|l|}{$\mathrm{CS} f_{c}, 0$} \\
\hline & & $P$-value & $\operatorname{Var}(\%)$ & $P$-value & $\operatorname{Var}(\%)$ & $P$-value & $\operatorname{Var}(\%)$ & $P$-value & $\operatorname{Var}(\%)$ \\
\hline Site $(S)$ & 3 & 0.2443 & 3.4 & 0.0573 & 4.8 & 0.2326 & 2.3 & 0.0502 & 5.8 \\
\hline Tree/Site $(T / S)$ & 16 & 0.0001 & 30.2 & 0.0032 & 6.8 & 0.0001 & 16.9 & 0.0004 & 8.5 \\
\hline Height level $(L)$ & 2 & 0.0001 & 5.6 & 0.6162 & 0 & 0.6391 & 0 & 0.7593 & 0 \\
\hline$S * L$ & 6 & 0.8951 & 0 & 0.2818 & 0.5 & 0.0270 & 1.3 & 0.9035 & 0 \\
\hline$L * T(S)$ & 32 & 0.0001 & 7.4 & 0.9752 & 0 & 0.9980 & 0 & 0.1749 & 3.7 \\
\hline Radial position $(P)$ & 2 & 0.0001 & 15.5 & 0.0001 & 10.7 & 0.0001 & 26.7 & 0.0001 & 12.8 \\
\hline$S * P$ & 6 & 0.7010 & 0 & 0.8813 & 0 & 0.6290 & 0 & 0.3301 & 0.7 \\
\hline$P * T(S)$ & 32 & 0.0001 & 10 & 0.0363 & 8.5 & 0.0101 & 7.4 & 0.2136 & 3 \\
\hline$L * P$ & 4 & 0.0001 & 3.5 & 0.3468 & 0.3 & 0.0693 & 1.6 & 0.1762 & 1.2 \\
\hline$L * P * S$ & 12 & 0.0122 & 3.1 & 0.8293 & 0 & 0.2079 & 0.9 & 0.5111 & 0 \\
\hline$L * P * T(S)$ & 64 & 0.7429 & 0 & 0.9996 & 0 & 0.9995 & 0 & 0.6084 & 0 \\
\hline$R / P / L / T / S$ & 115 & & 21.2 & & 69 & & 43 & & 64.4 \\
\hline
\end{tabular}

$\operatorname{MOR} f_{\mathrm{m}}$ : bending strength; MOE $E_{0}$ : modulus of elasticity parallel to grain; $\mathrm{CS} f_{\mathrm{c}}, 0$ : compression strength parallel to grain. 


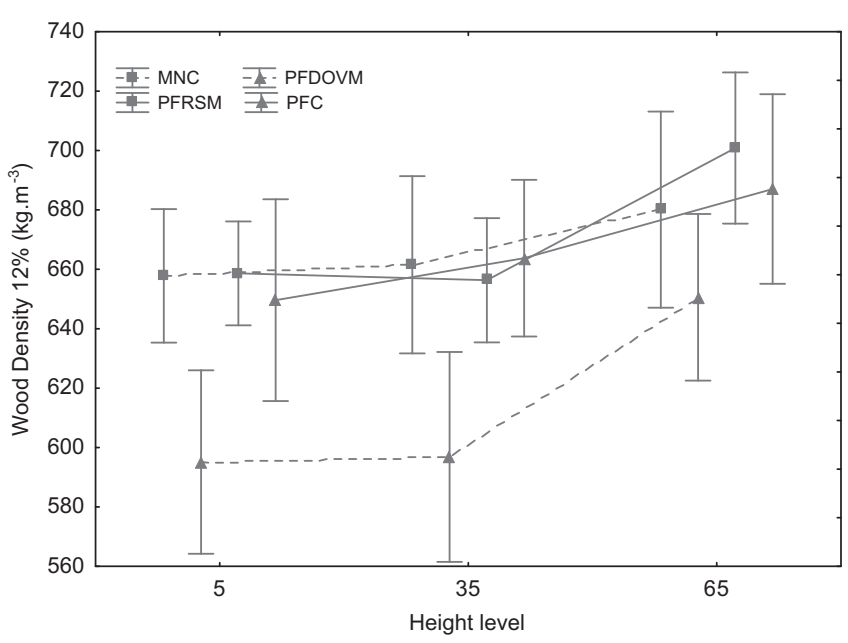

Fig. 3. Axial variation of wood density at $12 \%$ moisture content by site, for blackwood trees (mean and standard deviation).

The comparison with wood density values found in literature for A. melanoxylon showed similar mean values and variation. Nicholas and Brown [2] referred that there was remarkable variation in density between blackwood trees in New Zealand i.e. $465-670 \mathrm{~kg} \mathrm{~m}^{-3}$ in a group of 70 year-old trees, and considerable differences between seedlots. A range from 432 to $649 \mathrm{~kg} \mathrm{~m}^{-3}$ was reported [25]. Llic [26] referred an average of $546 \mathrm{~kg} \mathrm{~m}^{-3}$ (45 trees tested) and $566 \mathrm{~kg} \mathrm{~m}^{-3}$ (24 trees tested), and Ananias [27] found the highest values at $12.5 \mathrm{~m}$ height, of $500 \mathrm{~kg} \mathrm{~m}^{-3}$ and $520 \mathrm{~kg} \mathrm{~m}^{-3}$ for reaction and normal wood respectively. A large between-tree variation was also reported for the wood density of Argentinean blackwood trees, accounting for as much as $74 \%$ of the variation [18].

For the studied $A$. melanoxylon trees, density varied very little with height, but considerably over the radial profile. The highest values of density at stem base may result from a combined effect of cambial age (corresponding to $42 \pm 6$ years, as observed by wood ring counting) and of an influence from the root system. At the top of the trees, corresponding to the youngest material (approximately $10 \pm 4$ years) the lowest density values were expected (Fig. 3). A higher density at the stem base was also reported for young 6-year-old A. melanoxylon trees, growing in Australia, with an overall trend for reduction in density with tree height [28]. A low influence of tree height on wood density of blackwood trees was also observed for New Zealand blackwood trees [2] and for Argentinean blackwood trees [18].

\subsection{Mechanical properties}

Mechanical properties of blackwood are summarized in Table 3: average bending strength (MOR) of blackwood was $139 \mathrm{~N} \mathrm{~mm}^{-2}$, varying between sites from 126 to $146 \mathrm{~N} \mathrm{~mm}^{-2}$; average modulus of elasticity (MOE) in compression parallel to grain was $141 \times 10^{2}$ $\mathrm{N} \mathrm{mm}^{-2}$, varying from 132 to $146 \times 10^{2} \mathrm{~N} \mathrm{~mm}^{-2}$; and average compression strength parallel to the grain was $61 \mathrm{~N} \mathrm{~mm}^{-2}$, varying from 58 to $63 \mathrm{~N} \mathrm{~mm}^{-2}$.

Site was not a significant source of variation for the properties tested (Table 4). In all cases, the tree-to-tree variation was a significant source of variation and explained $6.8 \%$ of the bending strength variation, $16.9 \%$ of the MOE variation and $8.5 \%$ of the CS variation (Table 4).

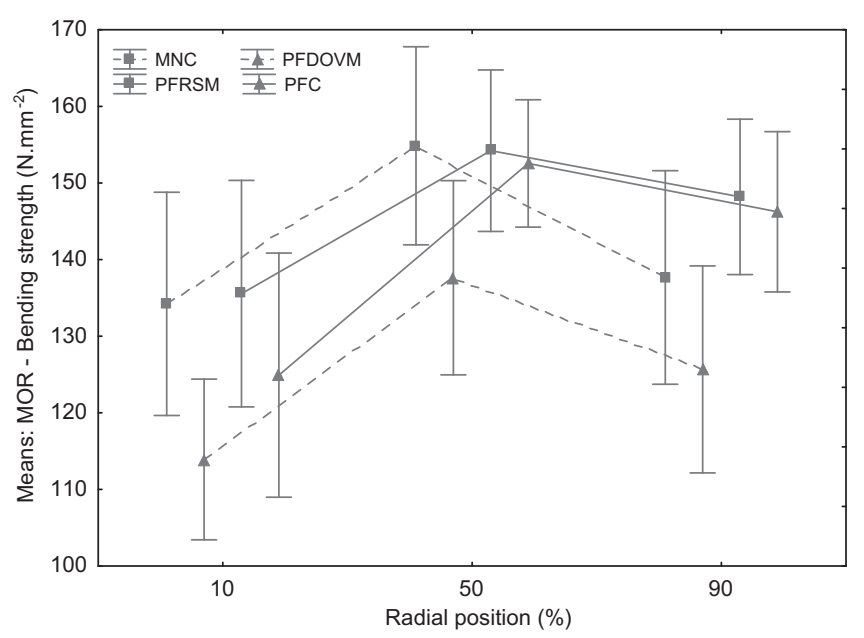

Fig. 4. Radial variation of bending strength (MOR) by site, for blackwood trees (mean and standard deviation).

The most important and highly significant source of variation in blackwood mechanical properties was the radial position (Table 4), explaining $10.7 \%, 26.7 \%$ an $12.8 \%$ of the total variation of the respective bending strength, MOE and CS.

Bending strength, MOE and CS increased from the $10 \%$ to the $50 \%$ radial position, followed by a small decrease to the $90 \%$ position (Fig. 4). This pattern of variation was site independent (Fig. 4), but for bending strength and MOE it may be slightly different from tree to tree (Table 4).

Blackwood mechanical properties did not vary with tree height (Table 4). Overall, this European grown blackwood showed to be a medium strength wood with mechanical properties similar to those reported for blackwood in Australia and New Zealand: $115-130 \mathrm{~N} \mathrm{~mm}^{-2}$ for MOR, $107 \times 10^{2} \mathrm{~N} \mathrm{~mm}^{-2}$ for MOE and 60-63 $\mathrm{N} \mathrm{mm}^{-2}$ for CS $[29,30]$. Blackwood also compares favorably to the prized teak wood that shows $141 \mathrm{~N} \mathrm{~mm}^{-2}$ for MOR, $132-144 \times 10^{2} \mathrm{~N} \mathrm{~mm}^{-2}$ for MOE and $50 \mathrm{~N} \mathrm{~mm}^{-2}$ for CS [31]. Maritime pine, the main timber species which grows together with blackwood (in mixed stands) shares the stands, has overall lower values of wood density, MOR, MOE and CS: $630 \mathrm{~kg} \mathrm{~m}^{-3}$, $130 \mathrm{~N} \mathrm{~mm}^{-2}, 105 \times 10^{2} \mathrm{~N} \mathrm{~mm}^{-2}$ and $47 \mathrm{~N} \mathrm{~mm}^{-2}$, respectively [32].

\subsection{Correlation of density with mechanical properties}

The wood density of individual samples moderately correlated with the mechanical properties of MOR, MOE and CS, although the determination coefficient was low, especially for MOR and CS ( 0.26 and 0.21 ) with the best case being MOE (0.42) (Table 5). Therefore a reliable prediction of wood strength and stiffness based on density is not possible for individual wood samples due to its low predictive ability, even if the significance of the correlation is high due to the high number of degrees of freedom. When considering the mean tree values, the determination coefficient were higher: MOE 0.53, MOR 0.64 and CS 0.45 (Table 5).

The relationship between wood density and strength properties is generally acknowledged in part because density is a measure of the relative amount of solid cell wall [32], but the correlations are highly dependent on species [33-36]. Low density correlations with mechanical properties were in some cases attributed to the influence of microfibril angle (MFA) [33,32,36]. The reasoning is that density increases while MFA decreases with age, thereby impacting the mechanical tests and resulting in poor correlations 
Table 5

Correlation of wood density at $12 \%$ moisture content with mechanical properties of blackwood at tree level (average values per tree) and at specimens test.

\begin{tabular}{lllll}
\hline & & $\mathrm{MOR}\left(\mathrm{N} \mathrm{mm}^{-2}\right)$ & $\mathrm{MOE}\left(\mathrm{N} \mathrm{mm}^{-2}\right)$ & $\mathrm{CS}\left(\mathrm{N} \mathrm{mm}^{-2}\right)$ \\
\hline Specimens level & $n$ & 221 & 197 & 254 \\
& $R^{2}$ & 0.26 & 0.42 & 0.21 \\
& $P$-value & 0.0000 & 0.0000 & 0.0000 \\
Tree level & $n$ & 20 & 20 & 20 \\
& $R^{2}$ & 0.64 & 0.53 & 0.45 \\
& $P$-value & 0.0000 & 0.0003 & 0.012 \\
\hline
\end{tabular}

MOR - bending strength; MOE - modulus of elasticity; CS - compression strength.

when density alone is considered [36]. The grain angle can also affect the correlation between density and mechanical properties [37].

High amounts of extractives can also influence mechanical properties, especially the compression strength, but also MOR [37-41]. The ethanol extractive content of blackwood heartwood is more than double that of the sapwood [9]. This could explain, at least in part, the decrease in MOR and CS from the 50\% (heartwood) to the $90 \%$ (sapwood) radial positions.

\subsection{Variability of properties}

Despite being a tough and adaptable species surviving across a range of different site and climatic conditions, blackwood is considered highly responsive to site factors $[2,3]$. In this study, four sites were tested which differ in type of soil and altitude, from sand at sea level (sites MNC and PFDOVM), to shallow granite soils at medium altitude (sites PFRSM and PFC) (Table 1 ).

The between-tree variation within a site was large for all wood properties and tree was always a highly significant factor of variation (Table 4). This influence of individual trees on the variation of wood properties constitutes a potential for selection and improvement especially for density.

As regards the within-tree variation, the radial variation was the most important for all wood properties (Table 4), thereby showing the importance of cambial age for the wood characteristics. The variation followed the common trend of increase from pith to bark that is linked to the tree age and the transition from juvenile to mature wood [13]. In this study, the radial position at $10 \%$ of the radius clearly is within the corewood but from $50 \%$ to the $90 \%$ position the properties leveled off (density and MOE) or decreased slightly (MOR, CS). A considerable variation of basic density over the radial profile was also reported for New Zealand blackwood [2].

However, the radial within-tree variation had a moderate range, thereby avoiding unfavorable heterogeneities that could have an impact on the stem technological quality.

It should be noted that a large part of the variation was unexplained by the measured factors, especially for the mechanical properties i.e. the residual effect was one of the largest sources of variation (density $21 \%$, MOE $43 \%$, MOR and CS above $60 \%$ ). The higher residuals for MOR and CS are explained by their higher dependence on the sample homogeneity e.g. the presence of a weak point.

\section{Conclusions}

Blackwood (A. melanoxylon) trees grown in Portugal showed a production of high quality wood at a rotation age of 40 years which may be directed for carpentry and high value wood products. The wood showed medium-to-high density, modulus of elasticity and strength and overall small within-stem heterogeneity. The mechanical properties of blackwood were not influenced by site. Blackwood has the potential therefore to be an alternative species to supply the European industry with valuable hardwood timber.

The significant differences found between the trees show the possibility of selection and improvement for increased wood quality.

\section{Acknowledgements}

The authors thank Mário Tavares, who selected the stands, Fátima Tavares who coordinated the sampling and Sofia Knapic who carried out the fieldwork. The financial support was given by Fundação para a Ciência e Tecnologia (Portugal), through Program FEDER/POCTI, Project AGR/42594/2001 and a scholarship granted to the third author SFRH/BD/42073/2007, and by the funding to Centro de Estudos Florestais (FEDER/POCTI 2010 and Pest-OE-AGR-UI0239-2011).

The authors would like to express their gratitude to Isabele Salavessa (IPCB Languages centre) for the English revision.

\section{References}

[1] Zwaan JG. The silviculture of blackwood (Acacia melanoxylon). South African Forest J 1982;121:39-43.

[2] Nicholas I, Brown I. Blackwood a handbook for growers and users. New Zealand: Rotorua; 2002.

[3] Bradbury GJ, Beadle CL, Potts BM. Genetic control in the survival, growth and form of Acacia melanoxylon. New Forest 2010;39(2):139-56.

[4] Instituto da Conservação da Natureza e das Florestas - $6^{\circ}$. Inventário Florestal Nacional, 1995|2005|2010. Áreas dos usos do solo e espécies florestais de Portugal continental, resultados provisórios. Ministério da Agricultura do Mar, do Ambiente e do Ordenamento do Território; 2013; 1: 13.

[5] Leite A, Santos C, Saraiva I, Pinho JO. Planeamento florestal e as espécies invasoras. In: SPCF, editor. $1^{\circ}$ Encontro Invasoras Lenhosas, Gerês, Portugal: 1999.

[6] Carvalho A. Madeiras portuguesas - vol. II. estrutura anatómica, propriedades, utilizações. Lisboa, DGF; 1977.

[7] Knapic S, Tavares F, Pereira H. Heartwood and sapwood variation in Acacia melanoxylon R. Br. Trees in Portugal. Forestry 2006;79(4):371-80.

[8] Santos A, Simões R, Tavares M. Variation of some wood macroscopic properties along the stem of Acacia melanoxylon R. Br. Adult trees in Portugal. Forest Syst 2013;22(3).

[9] Santos A, Amaral M, Gil N, Anjos O. Pereira H and Simões R influence on pulping yield and pulp properties of wood density of Acacia melanoxylon. J Wood Sci 2012:58(6):479-86.

[10] Anjos O, Santos A, Simões A. Effect of Acacia melanoxylon fiber morphology on papermaking potential. Appita J 2011;64(2):185-91.

[11] Lourenç A, Baptista I, Gominho J, Pereira H. The influence of heartwood on the pulping properties of Acacia melanoxylon wood. J Wood Sci 2008;54(6):464-9.

[12] Santos AJA, Anjos OMS, Simões RMS. Papermaking potential of Acacia dealbata and Acacia melanoxylon. Appita J 2006;59(1):58-64.

[13] Zobel BJ, van Buijtenen JP, editors. Wood variation: its causes and control. Springer series in wood science. Berlin (Germany): Springer-Verlag; 1989

[14] Anjos O, Rodrigues C, Morais J, Pereira H. Effect of density on the compression behaviour of cork. Mater Des 2014;53:1089-96.

[15] Priadi T, Hiziroglu S. Characterization of heat treated wood species. Mater Des 2013;49:575-82.

[16] Anjos O, Pereira H, Rosa ME. Tensile properties of cork in the tangential direction: variation with quality, porosity, density and radial position in the cork plank. Mater Des 2010;4(31):2085-90.

[17] Gowhari Anaraki AR, Fakoor M. General mixed mode I/II fracture criterion for wood considering T-stress effects. Mater Des 2010;31(9):4461-9.

[18] Igartúa DV, Monteoliva S. Densidad básica de la madera de Acacia melanoxylon R. Br. en relación con la altura de muestreo, el árbol y el sitio. Invest Agrar: Sist Recur For 2009;18(1):101-10.

[19] Aguilera A, Zamora R. Surface roughness in sapwood and heartwood of Blackwood (Acacia melanoxylon R. Br.) machined in 90-0 direction. Eur J Wood Wood Prod 2009;67(3):297-301.

[20] Igartúa DV, Monteoliva S, Piter JC. Study of some physical properties of Argentinean Acacia melanoxylon. Maderas-Cienc Tecnol 2009;11(1):3-18.

[21] Santos A, Teixeira A, Anjos O, Simões R, Nunes L, Machado J, et al. Utilização potencial do lenho de Acacia melanoxylon A Crescer em povoamentos puros ou mistos com Pinus pinaster pela indústria florestal portuguesa. Silva Lusitana 2007; 15(1):57-77.

[22] ISO standard 3131. Wood - determination of density for physical and mechanical tests. International Organization for Standardization; 1975

[23] ISO standard 3133. Wood - determination of ultimate strength in static bending. International Organization for Standardization; 1975. 
[24] ISO standard 3787. Wood - determination of ultimate stress in compression parallel to grain. International Organization for Standardization; 1976.

[25] Santos A, Alves A, Simões R, Pereira H, Rodrigues J, Schwanninger M. Estimation of wood basic density of Acacia melanoxylon (R. Br.) by near infrared spectroscopy. J Near Infrared Spec 2012;20(2):267-74.

[26] Llic J, Boland D, McDonald M, Downes G, Blakemore P. Woody density phase 1 - state of knowledge. CSIRO Forestry and Forest Products, Australian Greenhouse Office. National Carbon Accounting System Technical Report; No. 18. PANDORA electronic collection. 2000.

[27] Ananias A. Variation in basic density and shrinkage of wood from Acacia melanoxylon. Cien Invest Forestal 1989;6:118-30.

[28] Clark NB. Longitudinal density variation in irrigated hardwoods. Appita J 2001;54(1):49-53.

[29] Bolza E, Kloot NH. The mechanical properties of 174 Australian timbers. CSIRO Division of Forest Products Technical Paper No. 25. 1963.

[30] Haslett AN. Properties and utilization of exotic speciality timbers grown in New Zealand Part II. Australian blackwood Acacia melanoxylon R.Br. New Zealand Forest Service, Forest Research Institute. FRI Bull 1986;119(2).

[31] Miranda I, Sousa V. Pereira H wood properties of teak (Tectona grandis) from a mature unmanaged stand in East Timor. J Wood Sci 2011;57(3):171-8.

[32] Machado JS. Cruz HP within stem variation of Maritime Pine timber mechanical properties. Holz Roh Werkst 2005;63(2):154-9.
[33] Yang JL, Evans R. Prediction of MOE of eucalypt wood from microfibril angle and density. Holz Roh Werkst 2003;61(6):449-52.

[34] Evans R, Ilic J. Rapid prediction of wood stiffness from microfibril, angle and density. Forest Prod J 2001;51(3):53-7.

[35] Rozenberg P, Franc A, Mamdy C, Launay J, Schermann N, Bastien JC. Genetic control of stiffness of standing Douglas fir from the standing stem to the standardised wood sample, relationships between modulus of elasticity and wood density parameters. Part II. Ann for Sci 1999;56(2):145-54.

[36] Cave ID, Walker JCF. Stiffness of wood in fast-grown plantation softwoods: The influence of microfibril angle. Forest Prod J 1994;44(5):43-8.

[37] Green DW, Winandy JE, Kretschmann DE. Mechanical properties of wood. In: USDA Forest Service FPL, editor. Wood handbook: wood as an engineering material, vol. 4. Madison WI; 1999, p. 1-45.

[38] Hernandez RE. Influence of accessory substances, wood density and interlocked grain on the compressive properties of hardwoods. Wood Sci Technol 2007:41(3):249-65.

[39] Grabner M, Muller U, Gierlinger N, Wimmer R. Effects of heartwood extractives on mechanical properties of larch. IAWA J 2005;26(2):211-20.

[40] Chopra JL, Gupta RC, Narayanamurti V. The influence of extractives on some properties of wood. Appl Sci Res 1959;8(1):61-4.

[41] Luxford RF. Effect of extractives on the strength of wood. J Agr Res $1931 ; 42(12): 801-26$. 